\title{
Pressure Dependence of the Curing Behavior of Epoxy Resin
}

\author{
Katsuhiko Nakamae, ${ }^{\dagger}$ Takashi Nishino, Xu AiRu, \\ and Kohro TAKatsuka* \\ Department of Industrial Chemistry, Faculty of Engineering, \\ Kobe University, Rokkodai, Nada, Kobe 657, Japan \\ * Polymers \& Composites Development Center, Kobe Steel, Ltd., \\ Wakinohama, Chuo, Kobe 651, Japan
}

(Received November 2, 1990)

\begin{abstract}
Epoxy resin of bisphenol A type/aromatic diamine system was cured under high pressure up to $1,000 \mathrm{MPa}$. Pressure dependence of the mechanical and thermal properties of cured epoxy resin was investigated. Mechanical properties such as Young's modulus, tensile strength and elongation at break, and the glass transition temperature decreased with increasing curing pressure, though high pressure showed no effect on density. The swelling ratio of the cured resin with toluene increased with increasing curing pressure, and the IR absorption band assigned to epoxy group remained for the epoxy resin cured at high pressure. These results show that high curing pressure increases the glass transition temperature, restricts the diffusion and collision of molecules and the rate of curing reaction slow down. Poor mechanical and thermal properties for the epoxy resin cured under high pressure are considered to be due to insufficient curing of these resins.

KEY WORDS Ultrahigh Curing Pressure / Epoxy Resin / Thermal Property

/ Mechanical Property / Curing Behavior /
\end{abstract}

Epoxy resin is used in many important fields as an excellent thermosetting adhesive and protective for metals and semiconductors. A lot of studies on the curing mechanism of epoxy resin $^{1}$ and also on the residual stress ${ }^{2}$ at the interface between metal and epoxy resin were reported, but little is known about the effects of pressure on curing behavior. It is well known that many reactions which could not be carried out under normal pressure, for example, polymerization of ethylene, can be carried out under high pressure. ${ }^{3}$ Pressure is considered to take part in various reactions for a many substances.

In this study, epoxy resin was cured under an ultrahigh pressure up to $1000 \mathrm{MPa}$, and the pressure dependence of the mechanical and thermal properties of cured epoxy resin was investigated.

\section{EXPERIMENTAL}

\section{Materials}

A liquid diglycidyl ether of bisphenol A type epoxy resin (Epikote 828; Shell Chemical Co.; $M_{n} 380$, epoxy equivalent $190 \pm 5, n=0.1$ ),<smiles>CC(C)(c1ccc(OCC(O)CCCCOc2ccc(C(C)(C)c3ccc(OCC4CO4)cc3)cc2)cc1)c1ccc(OCC(O)CC2CO2)cc1</smiles>

and 4,4'-diaminodiphenylmethane (DDM), an aromatic diamine curing agent,

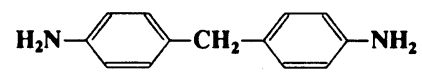

\footnotetext{
$\dagger$ To whom correspondence should be addressed.
} 


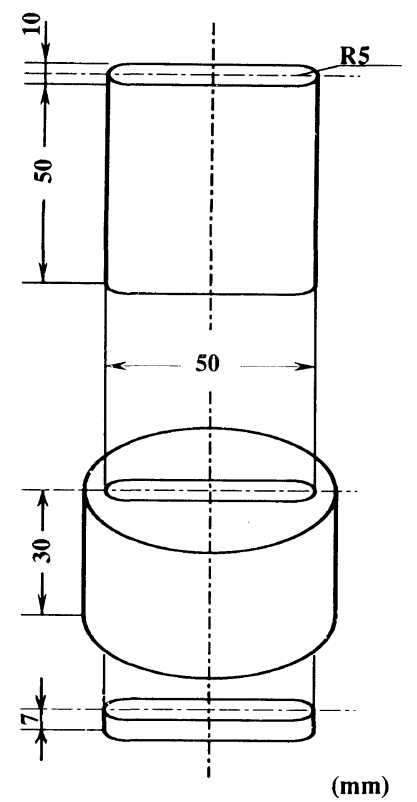

Figure 1. Schematic representation of the mold for curing at high pressure.

were used as the resin and curing agent in this study.

\section{Preparation of Specimen}

Epoxy resin was mixed with a stoichiometric amount $(20.7 \mathrm{wt} \%)$ of DDM at $80^{\circ} \mathrm{C}$, and the mixture was poured into a mold as shown in Figure 1. This mold could be pressed up to $1000 \mathrm{MPa}$ and was heated with an electric heater up to $200^{\circ} \mathrm{C}$ through a volt slider, and the temperature was measured with a thermocouple inserted in the mold.

Figure 2 shows the typical curing process at high pressure $\left(1000 \mathrm{MPa}, 200^{\circ} \mathrm{C}, 1.5 \mathrm{~h}\right)$. The mixture was subjected to a pre-selected final pressure at room temperature followed by heating from room temperature to a curing temperature. It took $30 \mathrm{~min}$ to elevate the mold temperature to the required temperature, and after that the curing process was considered to start. After curing at $200^{\circ} \mathrm{C}$ for $1.5 \mathrm{~h}$, the mixture was cooled down gradually while maintaining the pressure at $1000 \mathrm{MPa}$. When the temperature reached $120^{\circ} \mathrm{C}$, which is below

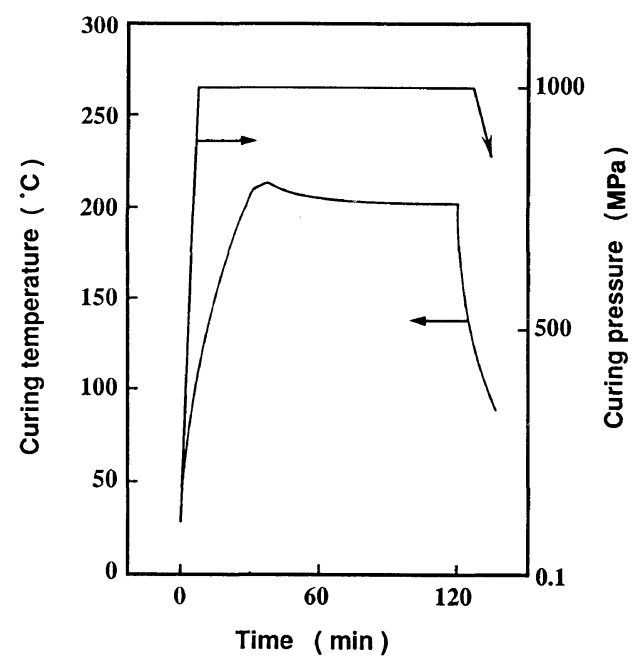

Figure 2. Relationships between curing temperature, curing pressure and time for a typical curing process.

the glass transition temperature, the pressure was released. The cured samples were $50 \mathrm{~mm}$ $\times 10 \mathrm{~mm} \times$ thickness $1 \mathrm{~mm}$. They were stored in a desiccator at room temperature.

\section{Measurement}

Mechanical properties of samples were measured by a tensile tester (Shimadzu, Autograph SD-100) at $25^{\circ} \mathrm{C}$. The initial length of the specimen was $40 \mathrm{~mm}$ and the extension rate was $5 \mathrm{~mm} \mathrm{~min}^{-1}$.

Thermal analysis was carried out on a differential scanning calorimeter (Daini Seikosha, SSC-560S) at a heating rate of $10^{\circ} \mathrm{C} \mathrm{min}^{-1}$ from room temperature to $200^{\circ} \mathrm{C}$ at ambient pressure. Sample weight was $10.0 \mathrm{mg}$. The system was calibrated with Indium. The glass transition temperature $T_{\mathrm{g}}$ and change in heat capacity $\Delta C_{\mathrm{p}}$ were measured as described below.

The density of epoxy resin cured under various pressures was measured by a floating method using $\mathrm{NaBr}$ aqueous solution at $30^{\circ} \mathrm{C}$.

The swelling ratio was evaluated by measuring the weight gain of a sample immersed in reflexing toluene for $4 \mathrm{~h}$ as follow:

$$
\text { Swelling ratio }=\left(w-w_{0}\right) / w_{0}
$$


where $w, w_{0}$ are the weight of swelled and original sample, respectively.

Infrared spectra were taken with FTIR (Shimadzu FTIR4200) spectrophotometer.

\section{RESULTS AND DISCUSSION}

\section{Epoxy Resin Cured at 0.1 MPa}

Figure 3 shows the relationship between the glass transition temperature $T_{\mathrm{g}}$ and curing time of epoxy resin cured under $0.1 \mathrm{MPa}$ ambient pressure at $180^{\circ} \mathrm{C}$ and $200^{\circ} \mathrm{C}$. $T_{\mathrm{g}}$ increased rapidly with curing time and reached a plateau at $167^{\circ} \mathrm{C}$ in both cases. Thus, it needs at least $1.5 \mathrm{~h}$ for sufficient curing at $200^{\circ} \mathrm{C}$. In order to determine the best curing conditions at $0.1 \mathrm{MPa}$, the mechanical properties of epoxy resin cured at different temperature were investigated.

Figure 4 shows the relationship between Young's modulus, tensile strength, elongation at break of epoxy resin cured for $4 \mathrm{~h}$ and curing temperature. In all cases, the fracture processes were brittle type, and the stress-strain curves did not show clear yield points. Mechanical properties increased with increasing curing temperature followed by decrease at $220^{\circ} \mathrm{C}$. The decrement at $220^{\circ} \mathrm{C}$ may be considered due

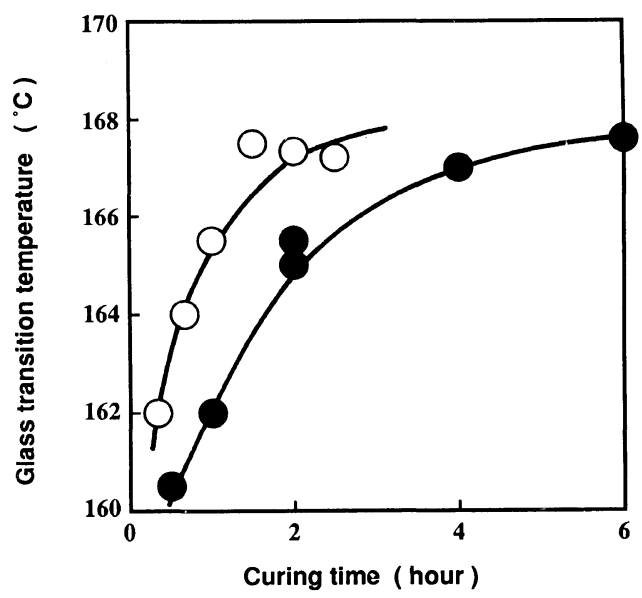

Figure 3. Relationship between glass transition temperature and curing time for epoxy resin cured under $0.1 \mathrm{MPa}$ at $(\mathrm{O}) 180^{\circ} \mathrm{C}$ and $(\mathrm{O}) 200^{\circ} \mathrm{C}$. to thermal degradation. $T_{\mathrm{g}}$ of epoxy resin cured at $150^{\circ} \mathrm{C}$ for $4 \mathrm{~h}$ was about $145^{\circ} \mathrm{C}$. Thus, the poor mechanical properties of epoxy resin cured at low temperature are considered due to insufficient curing. However, the density of the specimen was $1.197 \mathrm{~g} / \mathrm{cm}^{3}$, which is just the same that at $200^{\circ} \mathrm{C}$ for $4 \mathrm{~h}$. This indicates that density is not affected by curing degree, even though $T_{\mathrm{g}}$ and mechanical properties differed very much. In other words, $T_{\mathrm{g}}$ is a sensitive indicator whether curing is sufficient or not. As a result, epoxy resin cured at $200^{\circ} \mathrm{C}$ possessed both the highest $T_{\mathrm{g}}$ and best me-

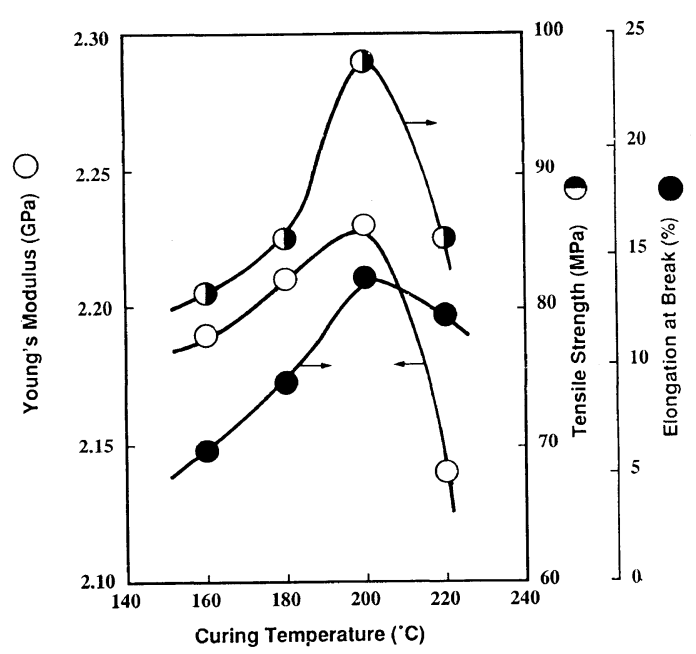

Figure 4. Relationship between $(\bigcirc)$ Young's modulus, (O) tensile strength, and (O) elongation at break and curing temperature for epoxy resin cured for $4 \mathrm{~h}$.

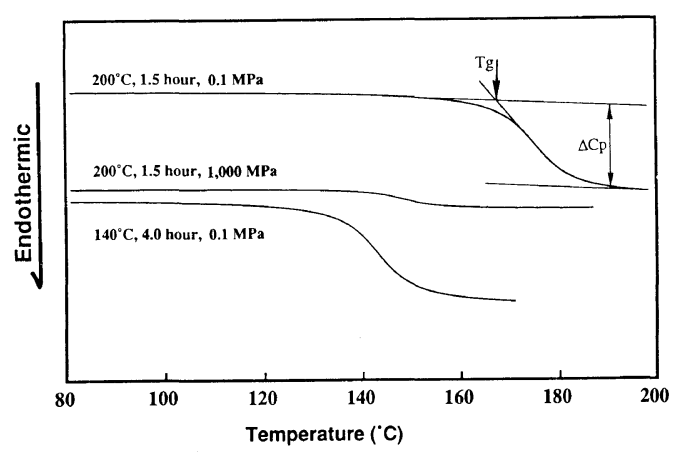

Figure 5. Thermograms of epoxy resins cured at $200^{\circ} \mathrm{C}$ for $1.5 \mathrm{~h}$ under $0.1 \mathrm{MPa}, 1000 \mathrm{MPa}$, and at $140^{\circ} \mathrm{C}$ for $4 \mathrm{~h}$ under $0.1 \mathrm{MPa}$. 
chanical properties in this system.

\section{Epoxy Resin Cured at High Pressure}

Figure 5 shows DSC thermograms of epoxy resin cured at $200^{\circ} \mathrm{C}$ for $1.5 \mathrm{~h}$ under $0.1 \mathrm{MPa}$ and $1000 \mathrm{MPa}$, respectively. The thermogram for epoxy resin cured at $140^{\circ} \mathrm{C}$ for $4.0 \mathrm{~h}$ under $0.1 \mathrm{MPa}$ is also shown in the figure. The arrow indicates $T_{\mathrm{g}}$, and change $\Delta C_{\mathrm{p}}$ in heat capacity with glass transition is defined as shown in figure. $\Delta C_{\mathrm{p}}$ of the epoxy resin cured at $140^{\circ} \mathrm{C}$,

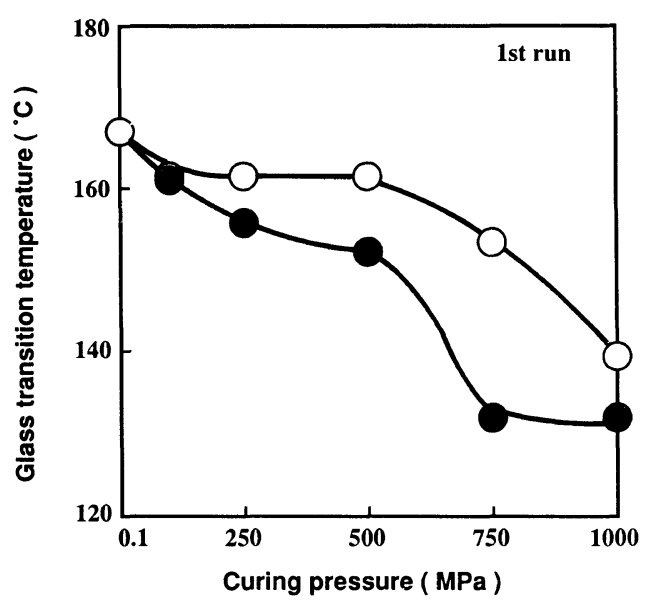

Figure 6. Relationship between glass transition temperature and curing pressure for epoxy resin cured at $200^{\circ} \mathrm{C}$ for $(\bigcirc) 2.5 \mathrm{~h}$ and $(O) 1.5 \mathrm{~h}$.

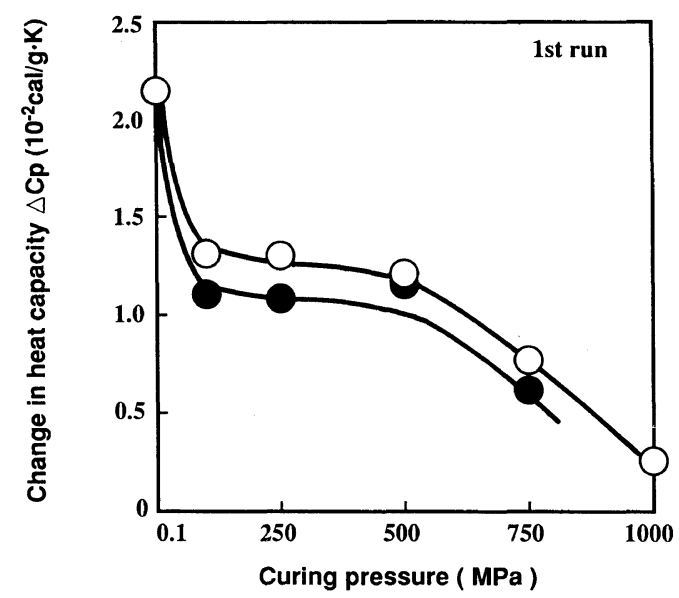

Figure 7. Relationship between change in heat capacity and curing pressure for epoxy resin cured at $200^{\circ} \mathrm{C}$ for (O) $2.5 \mathrm{~h}$ and (O) $1.5 \mathrm{~h}$.
$0.1 \mathrm{MPa}$ was almost as the same as that at $200^{\circ} \mathrm{C}, 0.1 \mathrm{MPa}$. However, epoxy resin cured at $1000 \mathrm{MPa}$ showed both low $T_{\mathrm{g}}$ and low $\Delta C_{\mathrm{p}}$.

Figures 6 and 7 show the relationships between $T_{\mathrm{g}}, \Delta C_{\mathrm{p}}$, and curing pressure for epoxy resin cured at $200^{\circ} \mathrm{C}$ for $1.5 \mathrm{~h}$ (filled circle) and $2.5 \mathrm{~h}$ (open circle). $T_{\mathrm{g}}$ decreased with curing pressure, and this tendency was more enhanced both for resins cured for $1.5 \mathrm{~h}$ and for those cured under a pressure of above $500 \mathrm{MPa} . T_{\mathrm{g}}$ and $\Delta C_{\mathrm{p}}$ are affected both by the thermal history of the specimen and time of the experiment. Wunderlich et al. conducted the thermal analysis of glasses formed under elevated pressure. ${ }^{4}$ They reported that the lower temperature limit of the glass transition

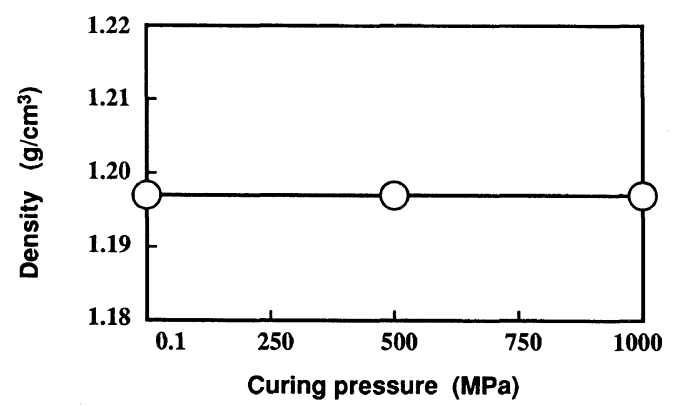

Figure 8. Relationship between density and curing pressure for epoxy resin cured at $200^{\circ} \mathrm{C}$ for $1.5 \mathrm{~h}$.

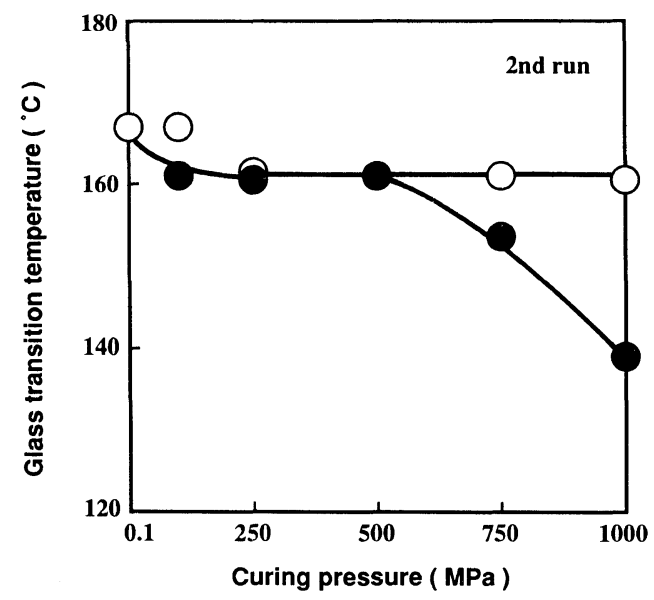

Figure 9. Relationship between glass transition temperature in the second run and curing pressure for epoxy resin cured at $200^{\circ} \mathrm{C}$ for $(\bigcirc) 2.5 \mathrm{~h}$ and (O) $1.5 \mathrm{~h}$. 
region shifted to lower temperature with increasing pressure, but the upper temperature limit of $T_{\mathrm{g}}$ was not significantly affected. This is in disagreement with the present data, in which both the lower and upper limits shifted to a lower temperature with increasing pressure.

Figure 8 shows the density of the epoxy resin cured at $200^{\circ} \mathrm{C}$ for $1.5 \mathrm{~h}$ under various pressures. While $T_{\mathrm{g}}$ and $\Delta C_{\mathrm{p}}$ decreased with increasing pressure, density remained un-

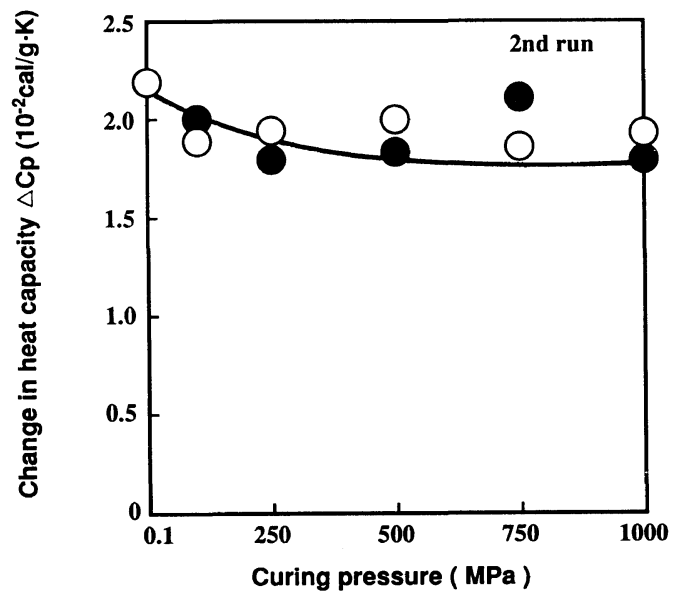

Figure 10. Relationship between change in heat capacity during the second run and curing pressure for epoxy resin cured at $200^{\circ} \mathrm{C}$ for $(\bigcirc) 2.5 \mathrm{~h}$ and $(\bigcirc) 1.5 \mathrm{~h}$.

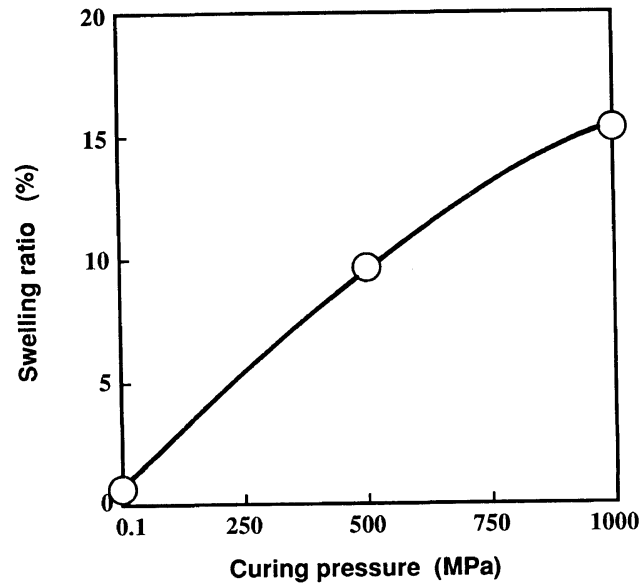

Figure 11. Relationship between swelling ratio with reflexing toluene and curing pressure for epoxy resin cured at $200^{\circ} \mathrm{C}$ for $1.5 \mathrm{~h}$ changed. This indicates that the pressure induced densification did not occur for this system within experimental error.

Figures 9 and 10 show the relationships between $T_{\mathrm{g}}, \Delta C_{\mathrm{p}}$, and the curing temperature of epoxy resin in the second run after heating to $200^{\circ} \mathrm{C}$ followed by slowly cooling to room temperature. $T_{\mathrm{g}}$ and $\Delta C_{\mathrm{p}}$ became nearly the same as those under $0.1 \mathrm{MPa}$, except for $T_{\mathrm{g}}$ of epoxy resin cured for $1.5 \mathrm{~h}$ under a pressure higher than $500 \mathrm{MPa}$. To investigate these phenomena, a swelling test with toluene was carried out.

Figure 11 shows the relationship between curing pressure and swelling ratio for epoxy resin cured at $200^{\circ} \mathrm{C}$ for $1.5 \mathrm{~h}$. The swelling ratio increased from $0.64 \%$ for $0.1 \mathrm{MPa}$ to

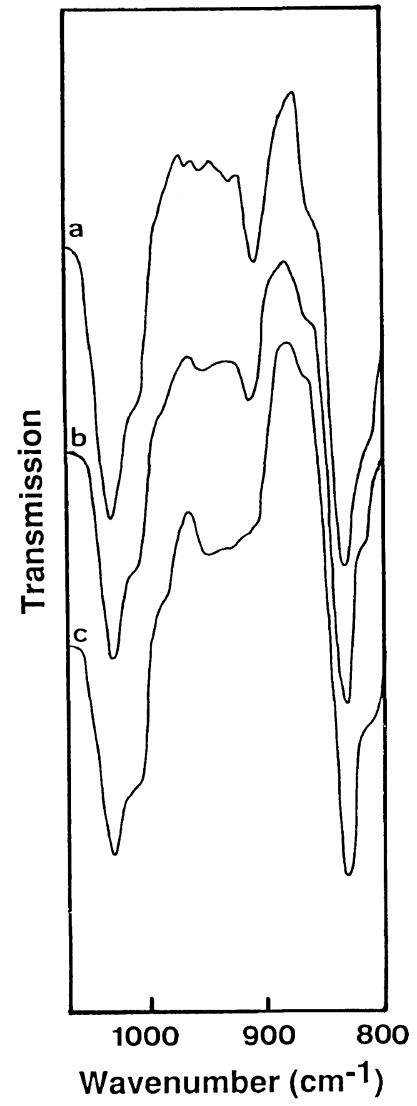

Figure 12. FT-IR spectra for epoxy resin cured under various conditions. a, $80^{\circ} \mathrm{C}, 1 \mathrm{~h}, 0.1 \mathrm{MPa} ; \mathrm{b}, 200^{\circ} \mathrm{C}, 1.5 \mathrm{~h}$, $1000 \mathrm{MPa} ; \mathrm{c}, 200^{\circ} \mathrm{C}, 1.5 \mathrm{~h}, 0.1 \mathrm{MPa}$. 
$16.3 \%$ for $1000 \mathrm{MPa}$ with increasing curing pressure. This indicates that crosslinking density decreased with increasing curing pressure. Thus, it is considered that high curing pressure would restrict the diffusion and collision of molecules, and accordingly, the rate of curing reaction would slow down. That is, it would take more time for epoxy resin to be cured completely at high pressure, and the glass transition temperature may increase. This is considered one reason for insufficient curing. The sample cured at high pressure may possess high $T_{\mathrm{g}}$ and sufficient cure, if cured at higher temperature and for a longer time provided thermal degradation does not occur. In order to clarify these points, the relationships between curing temperature/time/pressure should be examined. Hence, insufficient curing for the epoxy resin cured under high pressure is considered to be the cause of the decrement of $T_{\mathrm{g}}$. This insufficiency was almost recovered after curing at $0.1 \mathrm{MPa}$ as shown in Figures 9 and 10.

Figure 12 shows the FTIR spectra for epoxy resin cured under various conditions. The infrared band at $910 \mathrm{~cm}^{-1}$ may assigned to the epoxy group. ${ }^{5}$ This band was clearly observed for the resin cured at $80^{\circ} \mathrm{C}$ for $1 \mathrm{~h}$. It disappeared for the epoxy resin cured under $0.1 \mathrm{MPa}$ but it remained for that cured under $1000 \mathrm{MPa}$. This also supports insufficient curing for epoxy resin cured at high pressure.

Table I shows the mechanical properties of epoxy resin cured under various conditions. Because of the insufficient curing of epoxy resin under high pressure, properties were low compared with those cured at $200^{\circ} \mathrm{C}$ for $1.5 \mathrm{~h}$ under 0.1 MPa. Especially the tensile strength and elongation at break, in other words, mechanical properties at large deformation, depended strongly on curing conditions. This is considered due to mechanical properties in a small deformation region such as Young's modulus not being largely influenced by the
Table I. Mechanical properties of epoxy resin cured under various conditions

\begin{tabular}{|c|c|c|c|}
\hline \multirow{2}{*}{ Curing condition } & $\begin{array}{l}\text { Young's } \\
\text { modulus }\end{array}$ & $\begin{array}{l}\text { Tensile } \\
\text { strength }\end{array}$ & $\begin{array}{c}\text { Elongation } \\
\text { at break }\end{array}$ \\
\hline & $\mathrm{GPa}$ & $\mathrm{MPa}$ & $\%$ \\
\hline $200^{\circ} \mathrm{C}, 1.5 \mathrm{~h}, \quad 0.1 \mathrm{MPa}$ & 2.23 & 98.4 & 13.8 \\
\hline $200^{\circ} \mathrm{C}, 3.0 \mathrm{~h}, \quad 500 \mathrm{MPa}$ & 1.98 & 40.8 & 1.70 \\
\hline $200^{\circ} \mathrm{C}, 5.0 \mathrm{~h}, \quad 500 \mathrm{MPa}$ & 2.05 & 46.3 & 1.97 \\
\hline $200^{\circ} \mathrm{C}, 1.5 \mathrm{~h}, 1000 \mathrm{MPa}$ & 1.39 & 18.5 & 1.45 \\
\hline
\end{tabular}

number of crosslinkings in the glassy state.

\section{CONCLUSIONS}

Epoxy resin was cured under high pressure up to $1000 \mathrm{MPa}$. The glass transition temperature $T_{\mathrm{g}}$, change $\Delta C_{\mathrm{p}}$ in heat capacity and mechanical properties such as Young's modulus, tensile strength and elongation at break decreased with curing pressure. The high swelling ratio and residual IR band assigned to the epoxy group indicate that the cross linking density decreased with increasing curing pressure. It is considered that high pressure may restrict the diffusion and collision of molecules. Poor mechanical and thermal properties for epoxy resin cured under high pressure are considered due to the insufficient curing of the resin.

\section{REFERENCES}

1. H. Lee and K. Neville, "Handbook of Epoxy Resins," MacGraw-Hill, New York, N.Y., 1967.

2. M. Shimbo, M. Ochi, and Y. Shigata, J. Appl. Polym. Sci., 26, 2265 (1981).

3. K. E. Weale, "Chemical Reactions at High Pressures," E. and F. N. Spon Limited, London, 1967.

4. A. Weitz and B. Wunderlich, J. Polym. Sci., Polym. Phys. Ed., 12, 1473 (1974).

5. T. Okada and T. Asano, J. Adhesion Soc. Jpn., 23, 297 (1987). 